\title{
Changes in Community Behavior Patterns in Choosing Public Transportation Modes
}

\author{
$1^{\text {st }}$ Ridwan Tajul Fahmi \\ Universitas Negeri Malang \\ Indonesia \\ ridwanfahmi09@gmail.com \\ $2^{\text {nd }}$ Irine Kusuma Wardani \\ Universitas Negeri Malang \\ Indonesia \\ kusumawardani.irine@gmail.com
}

\author{
$3^{\text {rd }}$ Novita Indrasari \\ Universitas Negeri Malang \\ Indonesia \\ novitaindrasari77@gmail.com
}

\author{
$4^{\text {th }}$ Naula F.M Lainah \\ Universitas Negeri Malang \\ Indonesia \\ naula.lainah@gmail.com \\ $5^{\text {th }}$ Anny Mudahyana \\ Universitas Negeri Malang \\ Indonesia \\ annymudahyana9@gmail.com
}

\author{
$6^{\text {th }}$ Alan Sigit Fibrianto \\ Universitas Negeri Malang \\ Indonesia \\ alan.sigit.fis@um.ac.id
}

\begin{abstract}
This topic is interesting to discuss and examine because more and more people tend to use online motorcycle taxi transportation which is considered easier and more efficient. The emergence of this online motorcycle taxi illustrates that the community has begun to move to follow the era of industrial revolution 4.0 which maximizes the working data of communication and information technology well as a source of convenience for Salam transportation. The method used in this article uses a qualitative descriptive approach. The technique of collecting data uses observation, interviews and documentation. The results of this first study, changes in patterns of community behavior in transportation are supported by the existence of technology that facilitates application users. Secondly, there is an influence on the use and selection of public transportation towards conventional transportation which is starting to be empty of passengers due to the shift to online transportation which is considered easier and cheaper in withdrawing tariffs.
\end{abstract}

Keywords: behavior, change pattern, online transportation, technology

\section{INTRODUCTION}

Transportation is one of the tools that can facilitate people's mobility to move from one place to another. Transportation can reach places that are difficult to reach. Transportation is not only used by the upper classes but also can be used by the lower classes to the upper middle class. Transportation is divided into three namely land, water and air transportation. Besides according to its nature, transportation is divided into two namely public transportation and private transportation. At present transportation is divided into two namely conventional transportation and online transportation. Conventional transportation is public transportation that we usually use, which is already available on conventional roads. In Indonesia there are several types of conventional transportation such as buses, taxis, public transportation, bajaj, and motorcycle taxis. While online transportation is transportation through applications that have mobile phones or gadgets. Online transportation is by ordering through applications in Android gadgets. Online transportation began in Indonesia not long ago, unlike in foreign countries that have existed long ago. Technological sophistication today is very big role in the formation of new patterns of behavior for people everywhere [1]. The presence of technology creates consumption rationality in society [2].

In recent years, Indonesia has experienced a transformation in the field of transportation, namely the development of technology used to facilitate transportation. We can see this from the emergence of companies and online transportation models in Indonesia. At the beginning of the emergence of online transportation started by the uber application which was then followed by other online-based applications. The rise of the use of online transportation is inevitable because technology is now an important aspect of globalization and modernization. Therefore, every country, including Indonesia, must be able to compete with the use of technology and the application of technology in daily activities [3]

With the rise of the use of online transportation has caused some changes in behavior patterns in the community. One of them is the transition of the community in the use of conventional public transportation which moves using conventional modes of transportation. This is of interest to the author for further research on how changes in community behavior patterns in the choice of transportation modes, as well as how the influence of changes in community behavior patterns 
on conventional transportation. It aims to determine changes in people's behavior patterns in choosing modes of transportation and their effects on conventional transportation. Before I conducted this research, many other researchers were studying online transportation. But it does not focus on people's behavior in determining the choice between online transportation and conventional transportation.

Such as research conducted by Anwar [4] entitled 'online vs conventional: excellence and conflict between modes of transportation in the city of Makassar' research conducted by Amalia focuses on what are the advantages of online and conventional transportation. and how the dynamics of the community in accepting online transportation. Furthermore, the research conducted by Darmadi [5] entitled 'the impact of the existence of online transportation (gojek) on other public transportation in the city of Makassar' Darmadi in his research only focused on the impact caused by online transportation, in this case Gojek on conventional transportation. The two studies did not focus on changing people's behavior in choosing modes of transportation. Changes in community behavior can be understood as actions that start from the individual and are followed by other individuals who ultimately form patterns and lead to a new behavior in the community. Ojek online is a transportation service provider that is in high demand by the public. The convenience offered is one of the attractions for people to try online motorcycle taxi transportation services.

\section{METHOD}

This research use desciptive qualitative approach. The presence of researchers in the field in qualitative research as a research instrument as well as data collection. The researcher functions to determine the focus of the study, select the data source informant, collect data, and assess the quality of the data, analyze the data, interpret the data and make conclusions on the findings [6]. This research was conducted in February 2019 around Malang Kota Baru Station. The data obtained is sourced from the results of interviews with informants. Data collection techniques are carried out using the snowball rolling technique (Snowball technique) to find informants, namely online motorcycle taxi users and conventional motorcycle taxis, and people who work as online motorcycle taxis or conventional motorcycle taxis. This research was conducted by observation, interview, and documentation.

Data analysis is performed by collecting and grouping data, reducing data, presenting data, and drawing conclusions. Checking the validity of the data in this study was carried out with data triangulation. While the stages of this research include: 1) Observations made around the station, 2) Planning and developing research designs, 3) Conducting research, and 4) writing research reports in the form of scientific articles, in accordance with Guidelines for Writing Scientific Papers of State University of Malang.

\section{RESUlTS AND DISCUSSION}

The subjects studied in this study were students of Sociology, State University of Malang, and the object of this study was the behavior patterns of students who originally used conventional transportation services and switched to using online transportation services. In collecting data through interviews with about 15 sociology students of Malang State University where they are consumers or users of existing transportation services. After collecting the results of the interviews the researchers then analyzed and wrote the reviews obtained from the field results for discussion in the article with the abilities possessed by the researchers.

From the interviews it was also obtained that the online motorcycle taxi station was located on the Surabaya Canal road around the Malang State University campus. To be able to play in the region, there is a special community but does not require certain conditions to be able to join in the area. While around the Surabaya canal road which is only a few meters away is also a public transportation base for public transportation. The area is indeed strategic because it is often passed by students to go and return from campus for pedestrian students.

Changes in the use of transportation services experienced by many students who have been interviewed, the reason they change the use of transportation services is mostly a matter of convenience and also accuracy in the services provided. According to them the use of angkot transportation services is longer and the security provided is very minimal because of the large number of passengers who can provide opportunities for crime on the trip. While the use of these online transportation services they are given comfort and speed in service. Thus they use more online motorcycle taxi services than public transportation or conventional transportation. Changes in the pattern of use of online transportation services are reaping a lot of criticism and protest from each owner of conventional transportation services that are considered to have harmed and reduced their market share.

\section{A. Changes in Community Behavior Patterns in Selecting Transportation Modes}

The digital age affects all the joints of people's lives today. all the necessities of life can be fulfilled only through smart devices that are almost owned by everyone. Learning activities, buying tickets for travel, and buying goods can also be done with the smart device. Smart devices are inseparable in human life in the current era.

Changing times must be responded well by someone who wants to keep excision, and is not inferior to existing competition. If digitalization makes it easy for someone to fulfill their needs, then what is done by service providers or other goods in order to maintain their business is to digitize. This is done by transportation service companies such as Grab, Gojek, and Others. Through the application they developed, the motorcycle taxi mode has a place in the current digital era.

The application they developed aims to make it easier for motorcycle taxi service users to find motorcycle taxi drivers. By using only the smart device one can find a motorcycle taxi driver to be delivered to the place you want to go. Now not only to be delivered to the destination, Grab and Gojek also provide services to buy food, massage and clean the house. All can be ordered through an application that can be downloaded for free via the internet.

Ease of access and practicality in how to make Grab and Gojek widely used by many people. This is in accordance with the theory of rational choice put forward by Coleman, which 
states that a person's tendency for more actions that can maximize the use or desires and needs of his life [7]. In rational choice theory there are two elements in it, namely actors and resources [8]. Actors are individuals who have goals that must be met by their actions. Resources are something that can be controlled by the individual [9].

The actor here is someone who has a smart device that needs motorcycle taxi services. The action the actor will take is the action that he thinks is most beneficial and effective for him. Of course Grab and Gojek are certainly the most profitable and effective choices for actors in using motorcycle taxi services [10]. Without the need for him to go on a motorcycle taxi, he can be picked up by the motorcycle taxi driver at his place just one click away. The resource here is a motorcycle taxi where the actor can use his services freely by the actor. Actors would prefer a more profitable and effective way for him. Although he had to spend an effort to download the application, but this is better than having to walk first to the motorcycle taxi station. Conventional motorcycle taxi rates at the base are sometimes considered to lack clear standards, of course this is not found if we use the Grab or Gojek application.

\section{B. Effects of Changes in Community Behavior Patterns on Conventional Transportation}

A person's behavior can change as desired as well as environmental changes caused by increasingly sophisticated technology today. The convenience offered by technology makes people more likely to enjoy using the facilities provided. In this case Go-jek offers various facilities that can be enjoyed by every user, so that many people are interested in using Gojek to help with their daily activities.

The facilities offered by Go-jek are varied, ranging from Goride, Go-car, Go-Bluebird, Go-food, Go-send, Go-deal, Gopulse, Go-clean and many more. Thus the Go-jek user can choose whatever facilities he wants. This can facilitate the work of the community so that the appeal of the community to Go-jek can be assessed very high with the ease and facilities provided.

Thus the behavior patterns of people who generally use manual transportation services that usually customers or passengers who seek or come to a driver or motorcycle taxi driver in New Call can enjoy transportation services. However, it is different from Go-jek where customers or passengers will only operate applications that have been provided on the telephone and drivers will come or pick up customers wherever they want to make it easier for customers to transport.

Changing patterns of community transport behavior cause various impacts that occur on conventional transportation actors or conventional motorcycle taxis as well as on the community itself or passengers. The impact of which occurred is the first, conventional motorcycle taxis will be inferior to Go-jek which provides convenience in finding drivers without visiting the ojek base. Second, the reduction in conventional motorcycle taxi passengers because people prefer to use Go-jek which is easier. Third, the reputation of the conventional motorcycle taxi has drowned and is also very detrimental to conventional motorcycle taxis, because conventional motorcycle tax revenue is increasingly declining and difficult to find customers who are usually easily found in terminals, stations, markets, and other crowded places. Fourth, it appears that there are many opportunities in Go-jek. It is not uncommon for conventional ojegs to choose to move to Go-jek to keep earning income that can be considered better than conventional motorcycle taxi income that is uncertain. However, there are also conventional motorcycle taxis who choose to continue their work as conventional motorcycle taxis, they assume that there is already a fortune that regulates and assesses it is heavy enough to be a Go-jek who is required to be able to operate the applications that have been provided and also the target passengers that have been set to get additional bonuses.

Thus the apparent pattern of behavior is related to the theory of rational action triggered by Max Weber where social action can be understood as an individual choice that has a specific purpose, this theory focuses on the choice of each individual [5]. In this case it can be understood that each individual has the right to choose their own choice without the presence of certain groups who can impose his will, so they have the right to determine which transportation service will be used.

\section{CONCLUSION}

Change will indeed cause anxiety, especially for those who have been feeling very comfortable. Change is a threat. Likewise, the presence of online transportation is considered as a threat to a handful of people. With the progress of this changing era, conventional transportation is abandoned and replaced by transportation that is more easily found in this era of globalization. for example such as transportation services such as Grab, Gojek, and Others. This service company developed an application that made it easier for consumers to use motorcycle taxi services. With this application, consumers no longer need to painstakingly look for a motorcycle taxi because with this application they can easily find a motorcycle taxi driver. By only using this smart device they will be delivered to the place they are going. Changing patterns of community transport behavior cause various impacts that occur on conventional transportation actors. The impact created by the changes in the choice of transportation mode is very much for conventional transportation workers, the impact is divided into two parts, namely positive and negative impacts. First, positive impacts such as 1) in terms of effectiveness, online motorcycle taxi services are very efficient and easy to use by the community, especially in the millennial generation. 2) in terms of trust in the driver or driver of an online motorcycle taxi, that the driver has a working relationship with the company and automatically the drivers can be supervised by the company and are bound by the service standards of the company. 3) Furthermore, in terms of comfort, the comfort offered at this online motorcycle taxi includes driver friendliness, driving safety, and on the online motorcycle taxi they use a private car so that comfort and security is guaranteed, etc. While the negative impacts of this online motorcycle taxi include 1). Reducing the number of conventional transportation passengers, 2). Drowning conventional motorcycle taxi market share, and 3). Conventional transportation will be lost because it was replaced by Go-jek. Changing patterns of community transport behavior cause various impacts that occur on conventional transportation actors. 
The large number of online transportation that is currently surpassing conventional transportation is expected by the government to provide opportunities for improvement, opportunities to organize a better transportation system, opportunities to serve the public better so that conventional transportation is no less competitive with online transportation. This is the big work of the government and transportation industry stakeholders.

\section{REFERENCES}

[1] Fibrianto, A. S., \& Yuniar, A. D. (2019, June). Technological Development and its Impact on Community Social Behavior. In 1st International Conference on Social Knowledge Sciences and Education (ICSKSE 2018). Atlantis Press.

[2] Fibrianto, A., Yuniar, A., \& Irawan, M. (2018, August). 20. Rationality of Utilization and the Making of Virtual Democracy Using Smartphone Applications. In 5th International Conference on Social and Political Sciences (IcoSaPS 2018). Atlantis Press.
[3] Christiani, Lintang Citra. 2018. Dimensi McDonalisasi Lazada Online Mall: Sebuah Model Modernisasi Sistem Belanja. Jurnal Komunikasi dan Kajian Media, 1(2). (online) http://jurnal.untidar.ac.id/index.php/ komunikasi/article/view/757

[4] Anwar, A. A. (2017). Online vs konvensional: keunggulan dan konflik antar moda transportasi di kota makassar. ETNOSIA: Jurnal Etnografi Indonesia, 2(2), 220-246.

[5] Darmadi, W. (2016). Dampak Keberadaan Transportasi Ojek Online (GO-JEK) Terhadap Transportasi Angkutan Umum Lainnya di Kota Makassar" (Doctoral dissertation, Univeritas Islam Negeri Alauddin Makassar).

[6] Moleong, L. J. (2007). Metodologi Penelitian Kualitatif. Bandung: PT Remaja Rosda Karya.

[7] Arisandi, Herman. 2015. Buku Pintar Pemikiran Tokoh-tokoh Sosiologi Dari Klasik sampai Modern. Yogyakarta: IRCiSoD.

[8] Bachtiar, Wardi. 2013. Sosiologi Klasik. Bandung: PT Remaja Rosdakarya.

[9] Siahaan, Hotman M. 1986. Pengantar ke Arah Sejarah dan Teori Sosiologi. Jakarta: Erlangga.

[10] Angga, Aptaguna, \& E., Pitaloka. 2016. Pengaruh Kualitas Layanan dan Harga Terhadap Minat Beli Jasa Go-Jek. Jurnal Widyakala, (3). (Online) http://ojs.upj.ac.id/index.php/journal_widya/article/view/24 